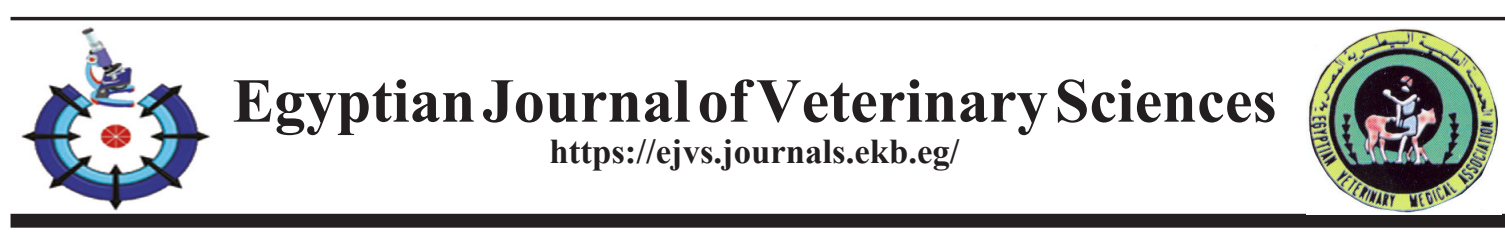

\title{
Changes in Alpha-fetoprotein, Phosphorus, Calcium, and Metabolic Hormones in Goats had Singleton, Twin, and Triplet Pregnancy
}

\author{
Omnia M.Z. El-sayed ${ }^{1}$, Mohamed M.M. Kandiel², Karima Gh. M. Mahmoud ${ }^{3 *}$, \\ Mahmoud E.A. Abou-El-Roos ${ }^{2}$ and Sally Ibrahim ${ }^{3}$ \\ ${ }^{1}$ Kafr Shokr Veterinary Administration, Qalyubia, Egypt. \\ ${ }^{2}$ Department of Theriogenology, Faculty of Veterinary Medicine, Benha University, \\ Egypt. \\ ${ }^{3}$ Department of Animal Reproduction\& AI, National Research Centre, Dokki, 12622 \\ Giza, Egypt.
}

\begin{abstract}
T HE present study aimed to clarify the alternations in alpha-fetoprotein (AFP), phosphorus $(\mathrm{Ph})$, calcium $(\mathrm{Ca})$, and metabolic hormones (Growth hormones $(\mathrm{GH})$, insulin, and thyroid gland hormones) in singleton, twin, and triplet pregnancy in goats. Animals were examined for pregnancy ultrasonographically during mid-pregnancy (6-14 weeks of gestation), and were classified conferring to litter size into singleton $(n=55)$, twin $(n=25)$ and triple $(n=6)$ pregnancy, and non-pregnant status $(\mathrm{n}=64)$. Blood samples $(5 \mathrm{ml})$ were collected before ultrasound examination and serum was separated for analysis of alpha-fetoprotein, phosphorus, calcium, and GH, insulin, T3, and T4. The current data showed that the fetal numbers markedly influenced $\mathrm{AFP}, \mathrm{Ph}, \mathrm{Ca}, \mathrm{GH}$, insulin, T3 levels, but did not affect $\mathrm{T} 4$ and $\mathrm{Ph} / \mathrm{Ca}$ ratio. $\mathrm{AFP}$ levels were higher in twin $(\mathrm{P}<0.05)$ and triple $(\mathrm{P}<0.001)$ bearing does than in non-pregnant does $(56.00 \pm 5.00$ and $87.00 \pm 1.90$ vs $3.80 \pm .051 \mathrm{ng} / \mathrm{ml})$. Phosphorus and $\mathrm{Ca}$ levels declined with pregnancy, with the substantial decreased in multiple feti compared with non-pregnant does. Growth hormone imminently raised in twine and triple fetuses than non-pregnant does. Insulin levels elevated in triple compared to non- pregnant and singleton $(\mathrm{P}<0.005)$. Serum free T3 levels were lower in single and twin bearing does than non-pregnancy. In conclusion, fetal number markedly influenced the dam metabolic profile and mineral homostatis through altering AFP and metabolic hormones levels during pregnancy in goats.
\end{abstract}

Keywords: Alpha-fetoprotein, Fetal number, Goat, Growth hormones, Insulin, Thyroid hormones.

\section{Introduction}

It is well-known that animal reproductive status greatly influences hematobiochemical and hormonal profiles [1]. Moreover, the presence of more than one fetus contributes to a higher metabolic demand and increases the risks to nutritional deficiencies[2]. The fetal demands are met by remarkable changes in the endocrinological and biochemical milieu of the dam[3]. Goats have remarkable ability to adapt their metabolic and blood parameters to their physiological life stage[4].
Alpha fetoprotein (AFP) is produced during embryonic life primarily by fetal yolk sac then by the liver, and passes to the amniotic fluid via renal flow, traverses the placenta (probably by diffusion), and enters the maternal circulation [5]. AFP is positively correlated with the fetal development[6], and therefore it is considered as a good preterm biomarker for fetal developmental anomalies or abnormal pregnancy [7]. There is no former study estimated fetal or maternal serum AFP during pregnancy in goats. In ovine, the total fetal synthesis of AFP was highest during the late

Corresponding author: Karima Gh M. Mahmoud, E-mail: karimamahmoud@yahoo.com, Tel: 00201006316384

(Received 09/07/2021; accepted 26/08/2021)

DOI. 10.21608/ejvs.2021.84970.1249

C2022 National Information and Documentation Centre (NIDOC) 
middle and early latter third of pregnancy, while the maternal serum AFP showed a tendency increase during the last third of pregnancy [8]. In bovine, AFP was measurable from Day $16^{\text {th }}$ in placental tissue [9], and from Day $42^{\text {nd }}$ of gestation period in fetal fluids [10]. While AFP values in maternal plasma are unchanged throughout gestation, the maximal concentrations of AFP in fetal plasma and fetal fluids are reached between the $3^{\text {rd }}$ and $4^{\text {th }}$ month of gestation, and decline thereafter[10].

The mineral requirements for pregnancy are directly related to the stage of fetal growth [11] as well as number and size of fetuses[12]. Phosphorus is essential in various aspects of energy metabolism and absorption, and contributes to skeletal tissue forming [13]. Calcium is essential for many biological processes during pregnancy, including bones and teeth formation, signal transduction, muscular contraction, enzymatic regulation, and blood coagulation [14].

Growth hormone $(\mathrm{GH})$ is required for normal lactation in ruminants [15] and galactopoiesis in goats[16], and regulates many aspects of metabolic activity [17]. Insulin is one of the hormones essential for regulation energy homeostasis [18]. Insulin hormone, synthesized in the pancreatic-cells, works at peripheral (modulate satiety signals) and central nervous system (restrict food intake) levels and controls glucose transport in response to hyperglycemia[19]. During early gestation period, insulin creates an anabolic environment in the fetus supplied with optimal nutrients, whereas during late pregnancy it functions as a glucoregulatory hormone[20]. Throughout late gestation, insulin deficiency after fetal pancreatectomy causes growth retardation [21].

Appropriate thyroid gland function is crucial to sustain the productive performance in domestic animals (growth, milk, hair fiber production). Thyroid hormones are involved in maintaining the homeostasis of energy and protein metabolism, thermoregulation, growth, and productivity parameters [22]. Circulating thyroid hormones can be used as indicators for metabolic and nutritional status of the animals [23, 24].

The reproductive status is greatly inspired by blood levels of metabolites and metabolic hormonal in goats [25]. However, information about the biochemical profile and its relationship with fetal number is essential for mother nutritional requirements. Therefore, the current study aimed at verifying the influence of fetal number on maternal circulating alpha-fetoprotein, phosphorus, calcium, and metabolic hormones (Growth hormone, insulin, T3 and T4) in goats during mid-stage of pregnancy.

\section{Materials and Methods}

Animals

This study was conducted in Meet Kenana village, Qalubia, Egypt on a total number of 150 goats, aged $3.11 \pm 0.18$ years and weighed 44.53 $\pm 0.93 \mathrm{~kg}$. Animals were examined for pregnancy ultra-sonographically during mid-pregnancy (614 weeks of gestation), and were classified conferring to litter size into singleton $(\mathrm{n}=55)$, twin $(\mathrm{n}=25)$ and triple $(\mathrm{n}=6)$ pregnancy, and non-pregnant status $(\mathrm{n}=64)$.

\section{Collection of blood samples}

Blood samples $(5 \mathrm{ml})$ were collected, aseptically and carefully to avoid hemolysis, from each goat before ultrasound examination through jugular venipuncture into plain vacutainer tubes. Serum was separated by centrifugation at 2500 $\mathrm{rpm}$ for 15 minutes and stored at $-20^{\circ} \mathrm{C}$ till analysis.

\section{Determination of serum alpha fetoprotein}

Alpha fetoprotein was measured using a magnetic microparticle chemiluminescence immunoassay (Unicel DXI800; Beckman Coulter, Brea, CA, USA).

Determination of serum phosphorus and calcium levels

Serum inorganic phosphorus $(\mathrm{P})$ concentration was determined colorimetrically according to the method recorded by El-Merzabani[26] at 640 nm using a commercial kit (Cat. No. PH 1710) supplied by BIO-DIAGNOSTIC, Giza, Egypt.

Serum calcium (Ca) concentration was determined colorimetrically according to the method described by Gindler and King [27] at 585 nm using a commercial kit (Cat. No. CA 1210) supplied by BIO-DIAGNOSTIC, Giza, Egypt.

\section{Determination of serum growth hormone}

Growth hormone was determined using commercial ELISA kits (Cat No. CSB-E13275G, CUSABIO Biotech. Company, China)according to manufacturer instructions at $450 \mathrm{~nm}$.

\section{Determination of serum insulin}

Insulin was determined using commercial ELISA kits (Cat No. LS-F10172-1, LSBio, WA, USA) according to manufacturer instructions at $450 \mathrm{~nm}$. 


\section{Determination of free serum T3 and T4}

Serum concentrations serum T3 (Cat. No. 10301) and T4 (Cat. No. 10303) were determined according to manufacturer instructions with the use of commercial Enzyme Immunoassay Test Kits $(B I O S \circledR$, Chemux Bioscience Inc., South San Francisco, USA).

\section{Statistical analysis}

Data were calculated and graphically presented as mean $\pm \mathrm{SE}$. Analysis of significance between means was done non-parametrically using Kruskal-Wallis test using statistical package for social sciences (IBM SPSS Statistics V.21). P value less than 0.05 indicated significant differences.

\section{$\underline{\text { Result }}$}

Serum AFP levels were generally higher in twin $(p<0.05)$, and triple $(p<0.001)$ bearing does than in non-pregnant does $(56.00 \pm 5.00$ and $87.00 \pm 1.90$ vs $3.80 \pm .051 \mathrm{ng} / \mathrm{ml})$.In addition, serum AFP was markedly $(p<0.05)$ higher in triple than single fetus (Fig. 1A).
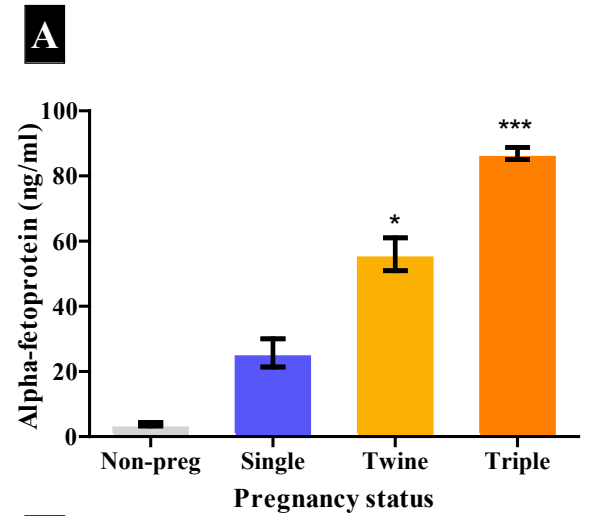

C

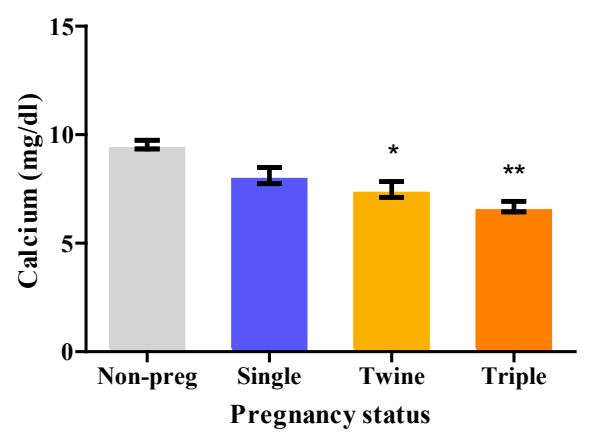

$\mathrm{P}$ and $\mathrm{Ca}$ levels declined with pregnancy status (Fig.1B-C), with the substantial decreased in twin $(p<0.05$ and $p<0.057)$ and triple $(p<0.01$ and $p<$ $0.005)$ bearing does when compared with nonpregnant does $(3.9 \pm 0.15 \& 3.9 \pm 0.06$ vs. $5.17 \pm 0.30$ $\mathrm{mg} / \mathrm{dl}$, and $7.48 \pm 0.36 \& 6.68 \pm 0.24$ vs $9.54 \pm 0.20$ $\mathrm{mg} / \mathrm{dl}$, respectively). Nevertheless, no marked differences in $\mathrm{Ca} / \mathrm{P}$ ratio between pregnant and non-pregnant cases (Fig.1 D).

Growth hormone concentration (Fig. 2A) was imminently higher in twine $(p<0.06)$ and triple $(p<0.001)$ fetuses than non-pregnant does $(3.20 \pm 0.36$ and $5.20 \pm 0.34$ vs $0.71 \pm 0.19 \mathrm{ng} / \mathrm{ml}$ ). Insulin levels (Fig. 2B) were higher in triple bearing does than non- pregnant $(p<0.06)$ and singleton $(p<0.005)(5.30 \pm 0.26$ vs $2.90 \pm 0.41$ and $1.80 \pm 0.48 \mu \mathrm{IU} / \mathrm{ml})$. Serum free T3 levels (Fig. 2C) were lower in single $(p<0.01)$, and twin $(p<0.05)$ bearing does $(10.00 \pm 1.20$ and $11.00 \pm 0.89$ vs. $16.00 \pm 1.10 \mathrm{ng} / \mathrm{ml}$, respectively). Nevertheless, T4 levels (Fig. 2D) were not distinctly varied between pregnant and nonpregnant conditions.

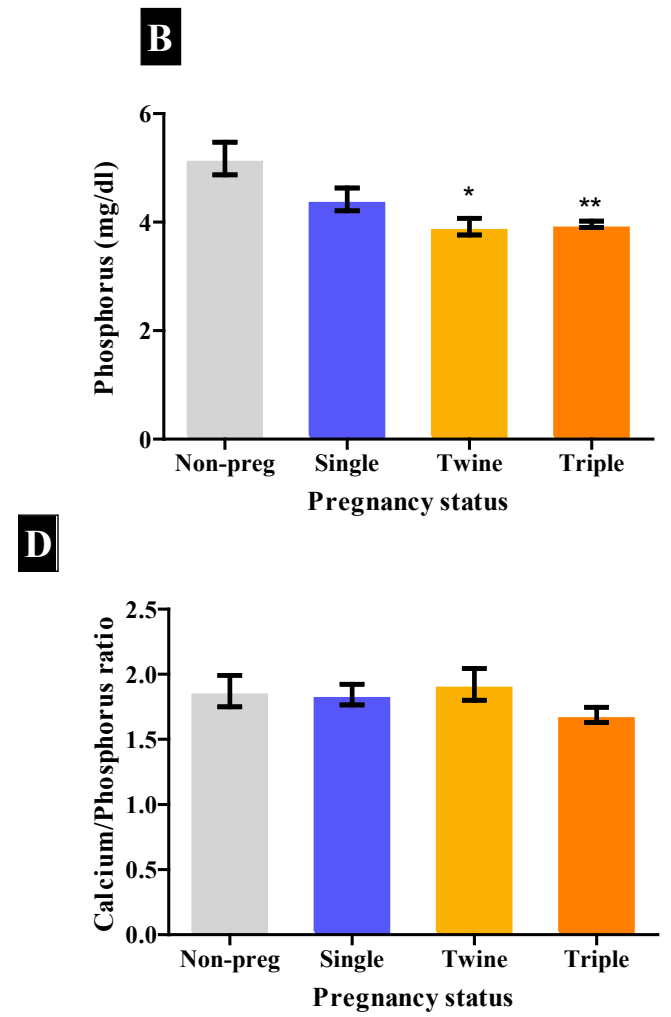

Fig. 1. Changes in alpha-fetoprotein (A), inorganic phosphorus (B), calcium (C), and calcium/phosphorus ratio (D) in non-pregnant $(\square)$ and pregnant (single $(\square)$, twin $(\square)$, and triple $(\square)$ ) goats during mid-stage of pregnancy. *, ** and *** signified significant differences at $\mathbf{P}<\mathbf{0 . 0 5}, 0.01$ and 0.001 compared with non-pregnant status. 

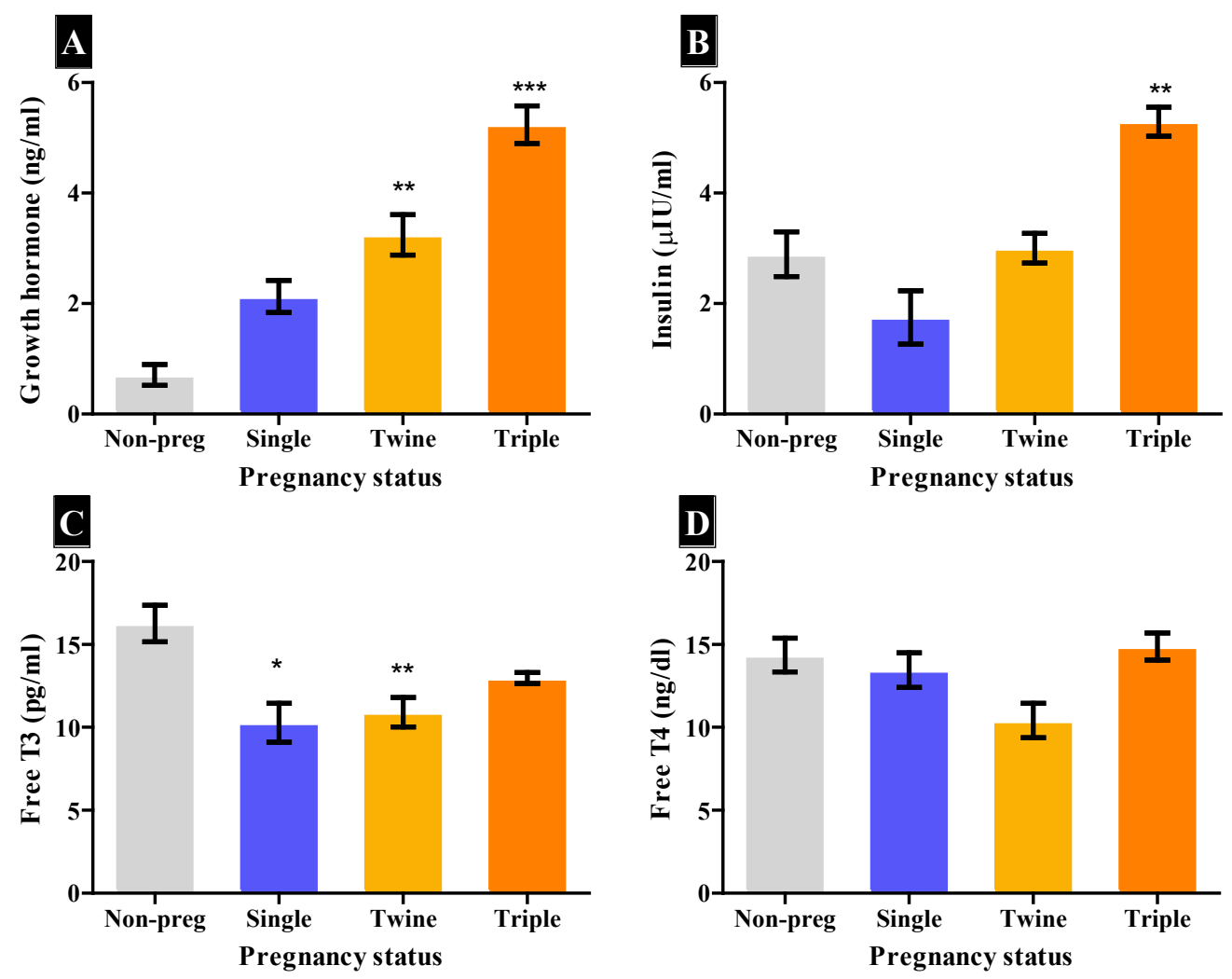

Fig. 2. Changes in growth hormone (A), insulin (B), Serum free T3 (C), and serum free T4 (D) in non-pregnant $(\square)$ and pregnant (single $(\square)$, twin $(\square)$, and triple $(\square)$ )goats during mid-stage of pregnancy. *,** and $* * *$ signified significant differences at $P<0.05,0.01$ and 0.001 compared with non-pregnant status.

\section{Discussion}

Goat is a well popular animal owned by many farmers for its high prolificacy with low costs rearing. They are considered to be highly adaptive animals that can mitigate body physiological and metabolic pathways. Increasing litter size contributes to a higher metabolic demand, thus increasing the risk of nutritional deficiencies [2, 28]. Many nutrients, minerals, and hormones concentrations change with respect to pre- and post-breeding stages [1]. In the present study fetal numbers markedly influenced AFP, $, \mathrm{Ca}, \mathrm{GH}$, insulin, T3 levels, but did not affect $\mathrm{T} 4$ and $\mathrm{P} / \mathrm{Ca}$ ratio.

Alpha-fetoprotein is produced by fetal liver during prenatal life, and decreased before birth, with only traces are detectable in adult circulation [29]. In the current study, Serum AFP levels surged in triple and twin bearing does than in non-pregnant does with higher levels in triple than single bearing does. These results were in accordance with Wald et al.[30] Xie et al. [31] and, Ren et al.[32], who declared that the median levels of maternal AFP were higher in the twin than singleton pregnancies. Formerly, it was found that the ovine fetal serum AFP concentrations increase during the $1^{\text {st }}$ trimester of pregnancy, and the total fetal AFP synthesis upsurge during the late middle and early latter trimester of pregnancy [8]. Bovine fetal plasma levels of AFP were maximal at 3-4 months of pregnancy, but decreased afterward until end of gestation period [10]. Detection of AFP in animals placental extract is related to its antioxidant properties [33, 34]. This effect involves inhibition of $\mathrm{H}_{2} \mathrm{O}_{2}$-induced apoptotic and cell death, and decreasing the intracellular reactive oxygen species levels [34].

In the current study, phosphorus and calcium levels markedly decreased with fetal numbers, being lower in triple and twins than non-pregnant animals. These finding agreed with Boass et al. [35], who noticed that an increased litter number and weight are associated with lower serum calcium in the mother. Recently, Mbegbu et al. [36] stated that calcium and inorganic phosphates 
concentrations significantly increased $(p<0.05)$ in the single compared with the twin bearing goats. Also, Yildiz et al. [37] reported that twin bearing sheep have lower serum calcium and phosphorus than singleton sheep. The decreased levels $\mathrm{Ca}$ and $\mathrm{P}$ in maternal serum might be accused to the increase in its retention the fetus and mammary gland with the pregnancy progression, and this helps in the preparation of the maternal body reserves for upcoming mineral demands[38]. It has been established that the daily requirements of $\mathrm{Ca}$ and $\mathrm{P}$ for pregnancy increased with fetal number (twin compared with single) and with pregnancy progression [39]. MichaLek et al.[40] stated that the kidneys efficiently regulate the calcium-phosphate balance in both single- and twin- pregnant goats. Despite the observed differences in the plasma inorganic phosphorus and calcium levels, these concentrations remained within the reference limits in subsequent weeks of gestation. Former researchers observed a decrease in the concentration of blood plasma calcium in pregnant sheep, and cows, laboratory animals and human being, and this was closely related to the number of fetuses in the uterus [4148]. On the other hand, serum phosphorus was observed modestly reduced in pregnant animals e.g., goats $[49,50]$, sheep $[51,50]$ and cows [50]. Nevertheless, some reports showed no change in plasma phosphorus concentration during pregnancy, neither in women nor in the females of other species, including goats $[11,52]$.

Nutritional intake of goats is influenced by pregnancy status especially during the final third of the gestational period regardless of the breed or type of pregnancy [53]. In the present study, metabolic hormones e.g., GH, insulin and T3 varied with pregnancy and fetal numbers. Growth hormone concentration in twins and triples, and insulin levels in triples increased, while T3 in single and twins decreased during pregnancy compared with non-pregnant does. These changes are urgently needed to accommodate the needs for fetal development. Castagnino et al.[53] showed that the fetal growth was $66 \%$ higher in twin pregnancies than in single pregnancies, and IGF-1 was maximal between 60 and 80 days of gestation. Abd-Elghany et al. [18] showed that the insulin was high, while thyroid hormones were low in metabolically distressed animals (pregnancy toxemia). GH levels significantly elevated in twin as compared to single bearing goats on the day of kidding, and declined thereafter [54]. The higher GH levels in twin fetus bearing goats may be due to lipolytic action of $\mathrm{GH}$ enable depot fat to be mobilized for energy for the parturition and initiation of lactation by increasing the availability of milk precursor to meet increased demand of energy for the initiation of milk secretion [55]. Studies in goats [54]and sheep [56]found that the levels of T3 and T4 were significantly higher in single bearing goats compared to the twin, especially at the end of pregnancy [57]. This is attributed to the lower maternal serum thyroid hormones levels in twin-bearing does, that are often characterized by negative energy balance, compared with single-bearing does (whose energy balance is usually less negative) [58]. In human studies, singleton pregnancies produce higher levels of hCG for longer periods, compared to twin pregnancies, which may result in a more pronounced physiological suppression of thyroid stimulating hormones[59]. Low thyroid gland hormones are the normal physiological response to conditions associated with energy preservation (and protein) characterizes a distinctive adaptive benefit, as in the case pregnancy in rat and her feti [60].Low T3 without change in T4 levels might indicate overactivity of thyroid gland function where removal of an iodine atom from T4 (four iodine atoms molecule) converts it to T3 (triiodothyronine)to face the dam and fetal requirements during pregnancy [61].

\section{Conclusions}

In conclusion, pregnancy status and type and litter size markedly influenced the dam metabolic profile and mineral balance through altering AFP and metabolic hormones levels during pregnancy in goats.

\section{Acknowledgement}

The authors would like to express their great thanks and appreciation to Dr. Mohamed Salama, the director of Meet Kenana Veterinary Clinic, Qalyubia Governorate, Egypt, for his great efforts and helps during the study.

\section{Conflict of Interest \\ None}

Funding statements

Nil

\section{Ethical consideration}

This study has been approved by the animal rights and ethical use committee of Benha University. 


\section{References}

1. Kandiel, M.M. M., El-Khaiat, H.M. and Mahmoud, K.Gh.M. Changes in some hematobiochemical and hormonal profile in Barki sheep with various reproductive statuses. Small Rumin. Res., 136, 87-95(2016).

2. Luke, B. Nutrition for Multiples. Clin. Obstet. Gynecol., 58, 585-610(2015).

3. Agarwal, S.P., Rai, A.K. and Khanna, N.D. Hormonal studies in postpartum female camels and their neonates. Theriog., 38,735-747(1992).

4. Sousa, N.M., Garbayo, J.M., Figueiredo, J.R., Sulon, J., Goncalves, P.D. and Beckers, J.F. Pregnancy associated glycoprotein and progesterone profiles during pregnancy and postpartum in native goats from the northeast of Brazil. Small Ruminant Res.,32, 137147(1999).

5. Ruoslahti, E. and Seppala, M. Alpha-fetoprotein in cancer and fetal development. Adv. Cancer Res.,29, 275-285(1979).

6. Madeeha, S., Waleed, S. and Subhan, S. Significance of Alpha Fetoprotein Levels for Fetal Growth and Tumor Monitoring. J.Microbiol. Pathol., 2(1), 105 (2018).

7. Tancrède, S., Bujold, E., Giguère, Y., Renald, M.H., Girouard, J. and Forest, J.C. Midtrimester maternal serum $\mathrm{AFP}$ and $\mathrm{hCG}$ as markers of preterm and term adverse pregnancy outcomes. J. Obstet. Gynaecol. Can., 37(2), 111-116(2015).

8. Lai, P.C., Mears, G.J., van Petten, G.R., Hay, D.M. and Lorscheider, F.L. Fetal-maternal distribution of ovine alpha-fetoprotein. Am. J. Physiol., 235(1), 27-31(1978).

9. Butler, J.E., Hamilton, W.C. , Sasser, R.G. , Ruder, C.A. , Hass, G.M. and Williams, R.R. Detection and partial characterization of two bovine pregnancy-specific proteins. Biol. Reprod., 26, 925-933(1982).

10. Smith, K.M., Lai, P.C., Robertson, H.A., Church, R.B. and Lorscheider, F.L. Distribution of alpha 1-fetoprotein in fetal plasma, allantoic fluid, amniotic fluid and maternal plasma of cows. J.Reprod.Fertil., 57(1), 235-238(1979).

11. Prentice, A. Maternal calcium metabolism and bone mineral status. Am. J. Clin. Nutr.,71, 13121315(2000).
12. Suttle, N.F. The Mineral Nutrition of Livestock, $4^{\text {th }}$ ed., CABI International. Wallingford, UK (2010).

13. Kumaresan, A. and Ndzingu Awa, D. Influence of age and pregnancy on serum calcium, inorganic phosphorus and alkaline phophatase activity in Red sokoto goats..Rev. Elev. Med. Vet. Pays. Trop., 37(4), 477 - 481(1984)

14. Weaver, C.M. and Heaney, R.P. Calcium. In Modern Nutrition in Health Disease, 11th ed.; Ross, A.C., Caballero, B., Cousins, R.J., Tucker, K.L., Ziegler, T.R., Eds.; Lippincott Williams \& Wilkins: Baltimore, MD, USA, 133-149(2014).

15. Meites, J. Farm animals: Hormonal induction of lactation and galactopoiesis. In: S. K. Ken and A. T. Cowie, eds. Milk, the mammary gland and its secretion, Vol. 2. Academic Press, New York, 321 p. (1961).

16. Cowie, A. T., and Tindal, J. S. The maintenance of lactation in the goat after hypophysectomy. $J$. Endocrinol., 23,79-96(1961).

17. Gluckman, P.D., Breier, B.H. and Davis, S.R. Physiology of the somatotropic axis with particular reference to the ruminant. J. Dairy Sci., 70, 442-466(1987).

18. Abd-Elghany, H., Seham, Y. and Saad, S. Some Immunohormonal changes in experimentally pregnant toxemic goats. Vet. Med. Int., 5,15(2010)

19. Regnault, T.R.H., Oddy, H.V., Nancarrow, C., Sriskandarajah, N. and Scaramuzzi, R.J. Glucosestimulated insulin response in pregnant sheep following acute suppression of plasma nonesterified fatty acid concentrations. Reprod. Biol. Endocrinol., 2, 64-74(2004).

20. Milner, R.D. and Hill, D.J. Fetal growth control: the role of insulin and related peptides. Clin. Endocrinol. (Oxf.), 21, 415-433(1984).

21. Fowden, A.L., Hughes, P. and Comline, R.S. The effects of insulin on the growth rate of the sheep fetus during late gestation. Q. J. Exp. Physiol.,74, 703-714(1989).

22. Huszenicza, G.Y., Kulcsar, M. and Rudas, P. Clinical endocrinology of thyroid gland function in ruminant.Vet. Med. Czech., 47,199-210(2002).

23. Riis, P.M. and Madsen, A. Thyroxine concentration and secretion rates in relation to pregnancy, lactation and energy balance in goats. J.Endocrin., 107, 421-427(1985). 
24. Todini, L., Malfatti, A., Valbonesi, A., Trabalza-Marinucci, M. and Debenedetti, A. Plasma total T3 and T4 concentrations in goats at different physiological stages, as affected by the energy intake. Small Rumin. Res., 68, 285-290(2007).

25. Fitz-Rodríguez, G., De Santiago-Miramontes, M.A., Scaramuzzi, R.J., Malpaux, B. and Delgadillo, J.A. Nutritional supplementation improves ovulation and pregnancy rates in female goats managed under natural grazing conditions and exposed to the male effect. Anim. Reprod. Sci., 116,85-94(2009).

26. El-Merzabani, M.M., El-Aaser, A.A. and Zakhary, N.I. A new method for determination of inorganic phosphorus in serum without deproteinization. J. Clin. Chem. Clin. Biochem., 15(12), 715-718(1977).

27. Gindler,E.M. and King, J.D. Rapid colorimetric determination of calcium in biologic fluids with methylthymol blue. Am. J. Clin.Path., 58(4), 376-382(1972).

28. Shinagawa, S., Suzuki, S., Chihara, H., Otsubo, Y., Takeshita, T. and Araki, T. Maternal basal metabolic rate in twin pregnancy. Gynecol. Obstet. Investig., 60, 145-148(2005).

29. Seppala, M. and Ruoslahti, E. Alpha fetoprotein: physiology and pathology during pregnancy and application to antenatal diagnosis. J. Perinat. Med., 1, 104-113(1973).

30. Wald, N.J., Barker, S. and Peto, R. Maternal serum alpha-fetoprotein in multiple pregnancy. British Med. J., 1, 651-652(1975).

31. Xie, Z., Lu, S., Zhu, Y., Sun, Y. and Jin, Y. Secondtrimester maternal serum free-betahuman chorionic gonadotropin and alpha-fetoprotein levels innormal twin and singleton pregnancies: A report of local Chinese population. Prenat.Diagn., 28, 735-738(2008).

32. Ren, F., Hu, Y., Zhou, H., Zhu,W.Y., Jia, L., $\mathrm{Xu}$, J.J. and Xue, J. Second trimester maternal serum triple screening marker levels in normal twin and singleton pregnancies. Biomed. Reports, 4, 475-478(2016).

33. Baker, M.E., Medlock, K.L. and Sheehan, D.M. Flavonoids inhibit estrogen binding to rat alpha-fetoprotein. Proc. Soc. Exp. Biol. Med., 217, 317-321(1998).
34. Choi, H.Y., Kim, S.W., Kim, B., Lee, H.N., Kim, S.J., Song, M., Kim, S., Kim, J., Kim, Y.B., Kim, J.H. and Cho, S.G. Alpha-fetoprotein, identified as a novel marker for the antioxidant effect of placental extract, exhibits synergistic antioxidant activity in the presence of estradiol. PLoS One, 9 (6), 99421(2014)

35. Boass, A., Garner, S.C., Schultz, V.L. andToverud, S.U. Regulation of serum calcitriol by serum ionized calcium in rats during pregnancy and lactation. J.Bone Miner. Res., 12, 909 -914(1997).

36. Mbegbu E.C., Anya K.O., Ugwuanyi H.E., Akanaga C.E. and Abiaezute C.N. Singleton and twin pregnancies in Red Maradi goats: changes in maternal serum biochemical composition and ovarian biometrics at mid gestation. Med. Weter., 77 (7), 353-357(2021).

37. Yildiz, A., Balikci, E. and Gurdogan, F. Serum mineral levels at pregnancy and postpartum in single and twin pregnant sheep. Biol. Trace Elem. Res.,107, 247-254(2005).

38. Härter, C.J., Castagnino, D.S., Rivera, A.R., Lima, L.D., Silva, H.G., Mendonça, A.N., Bonfim, G.F., Liesegang, A., St-Pierre, N. and Teixeira, I.A. Mineral Metabolism in Singleton and Twinpregnant Dairy Goats. Asian-Australas J. Anim. Sci., 28(1), 37-49(2015).

39. Härter, C.J., Lima, L.D., Castagnino, D.S., Silva, H.O., Figueiredo, F.O.M., St-Pierre, N.R., Resende, K.T. and Teixeira, I.A.M.A. Net mineral requirements of dairy goats during pregnancy. Animal, 11(9), 1513-1521(2017).

40. Michalek, K., Ozgo, M. and Skrzypczak, W. F. Renal regulation of calcium-phosphate metabolism in single- and twin pregnant goats. Folia Biol. (Kraków), 57, 199-205(2009).

41. Moniz, C.F., Nicolaides, K.H., Bamforth, F.J. and Rodeck, C.H. Normal reference ranges for biochemical substances relating to renal, hepatic and bon function in fetal and maternal plasma throughout pregnancy. J. Clin. Pathol., 38, 468474(1985).

42. Elias, E. and Shainkin-Kestenbaum, R. Hypocalcaemia and serum levels of inorganic phosphorus, magnesium, parathyroid and calcytonin hormones in the last month of pregnancy in Awassi fat-tail ewes. Reprod. Nutr., 30, 693-699(1990). 
43. Elzen, H.J., Wladimiroff, J.W., Overbeek, T.E., Morris, C.D. and Grobbe, D.E. Calcium metabolism, calcium supplementation and hypertensive disorders of pregnancy. Eur. J. Obstet. Gynecol. Reprod. Biol., 59, 5-16(1995).

44. Czajkowski, K. Calcium, magnesium and nonorganic phosphorus during diabeted complicated pregnancy. Habilitation Thesis. Med. Univ. Warsaw (1996) (In Polish).

45. Jankowiak, D., Skrzypczak, W.F. and Ozgo, M. Calcium, phosphorus and magnesium concentration in cows blood plasma during perinatal period. Physiology of perinatal and postnatal period of farm animals. Szczec in Barzkowice, 71-73(1997).

46. Kovacs, C.H and Kronenberg, M. Maternal-fetal calcium and bone metabolism during pregnancy, puerperium and lactation. Endocr. Rev., 18, 832872(1997).

47. Schrõder, B., Rittmann, I., Pfeffer, E. and Breves G. In vitro studies on calcium absorption from the gastrointestinal tract in small ruminants. J. Comp. Physiol.,167, 43-51(1997).

48. Kalkkwarf, H. J., Specker, B. L. and Ho, M. Effects of Calcium Supplementation on Calcium Homeostasis and Bone Turnover in Lactating Women. J. Clin. Endocrinol. Metab., 84, 464470(1999).

49. Barlet, J.P. Role physiologique de la calcitonine chez la chèvre gestanteouallaitante. Ann. Biol. Anim.Biochim.Biophys., 14, 447-457(1974).

50. Allen, W.M. and Sansom, B.F. Parturient paresis (milk fever) and hypocalcemia (cows, ewes, and goats). In: Current Veterinary Therapy: Food Animal Practice 2, edited by Howard JL. Philadelphia, PA: Saunders, ,311-320(1986).

51. Barlet, J.P., Argemi, B., Davicco, M.J. and Lefaivre, J. Plasma concentrations of 25-hydroxy vitamin $\mathrm{D}$ in pregnant and lactating ewes and foetal and newborn lambs. J.Endocrinol., 79, 149 $-150(1978)$.

52. Sarelo, O. K., Jankowiak, J. and Grzelak, J. Renal regulation of calcium-phosphate metabolism in pregnant goats. Medycyna Wet., 59, 1031-1034 (2003).

53. Castagnino, D.S., Härter, C.J., Rivera, A.R., Lima, L.D., Silva, H.G.O., Biagioli, B., Resende, K.T. and Teixeira, I.A.M.A. Changes in maternal body composition and metabolism of dairy goats during

Egypt. J. Vet. Sci. Vol. 53, No. 1 (2022) pregnancy. Revista Brasileira de Zootecnia, 44(3), 92-102(2015).

54. Khan, J.R. and Ludri, R.S.: Hormonal profiles during periparturientperiod in single and twin fetus bearing goats. Asian-Aust. J. Anim. Sci., 15(3), 346-351(2002).

55. Kornalijnslijper, J.E., Kemp, B., Bevers, M.M., Vanoord, H.A. and Taverne, M.A. M. Plasma prolactin, growth hormone and progesterone concentrations in pseudopregnant, hysterectomized and pregnant goats. Anim. Reprod. Sci., 49, 169-178(1997).

56. Yildiz, A., Balikci, E. and Gurdogan, F. Changes in some serum hormonal profiles during pregnancy in single- and twin-foetus-bearing Akkaraman sheep. Medycyna Weterynaryjna, 61, 1138-1141(2005).

57. Assane, M. and Sere, A. Seasonal and gestational variations of triiodothyronine and thyroxine plasma-concentrations in Sahel Peulh ewe. Annales de Recherches Veterinaires, 21, 285289(1990).

58. Manalu, W., Sumaryadi, M.Y. and Kusumorini, N. Maternal serum concentrations of total triiodothyronine, tetraiodothyronine and cortisol in different status of pregnancy during late pregnancy in Ettawah-cross does. Asian-Australasian Journal of Animal Sciences, 10, 385-390(1997).

59. Grun, J.P., Meuris, S., De Nayer, P. and Glinoer, D. The thyrotrophic role of human chorionic gonadotrophin (hCG) in the early stages of twin (versus single) pregnancies. Clin.Endocrinol. (Oxf.), 46,719-725(1997).

60. Calvo, R., Obregon, M.J., Ruiz de Oña, C., Ferreiro, B., Escobar Del Rey, E.and Morreale de Escobar, G. Thyroid hormone economy in pregnant rats near term: a "physiological" animal model of nonthyroidal illness? Endocrino., 127(1),10-16(1990).

61. Soldin, O.P. Thyroid function testing in pregnancy and thyroid disease: trimester-specific reference intervals. Therap. Drug Monitor., 28(1), 8-11(2006). 


\section{التغييرات في البروتين الجنيني ألفا والفوسفور والكالسيوم والهرمونات الأيضية في الماعز

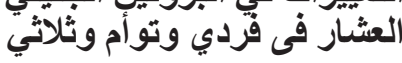 \\ أمنية محمد زيدان السيد'، محمد محمود مصطفى قنديل ، كريمه غنيمي محمودّ" ، محمود السيد عابد

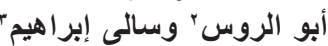

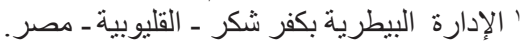

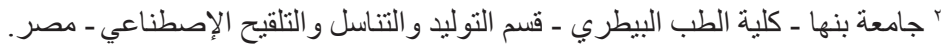

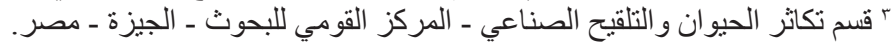

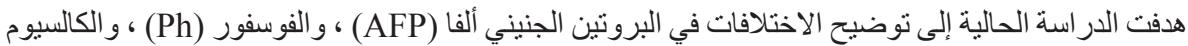

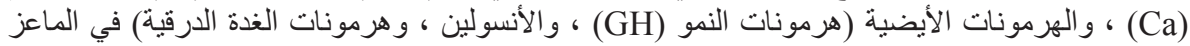

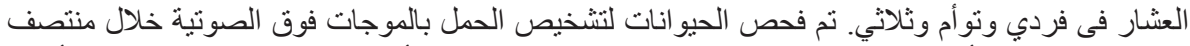

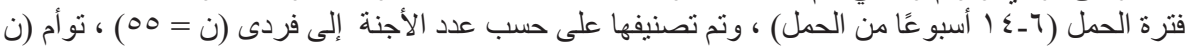

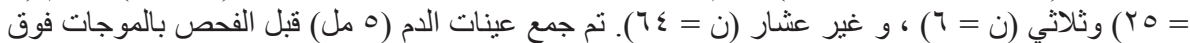

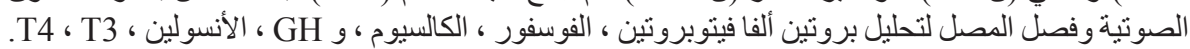

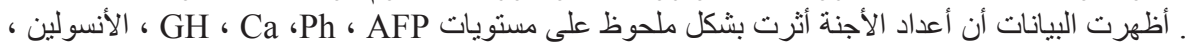

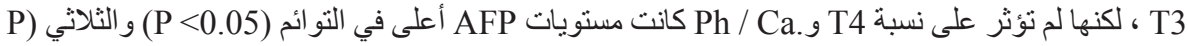

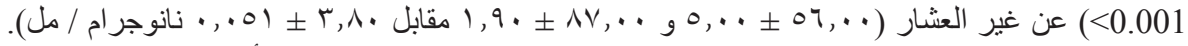

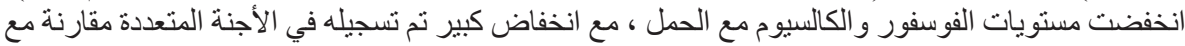

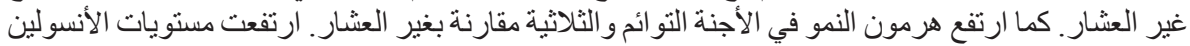

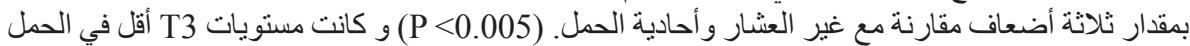

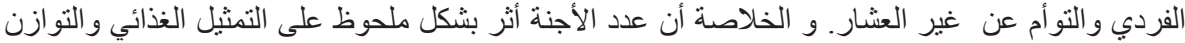

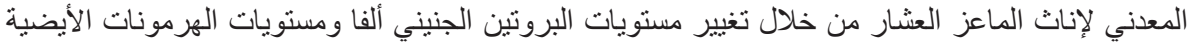
أثناء الحمل في الماعز. الماءز

الكلمات الدالة: البروتين الجنيني ألفا، عدد الأجنة ، ماعز ، هرمونات النمو ، الأنسولين ، هرمونات الغدة الدرقية. 